\title{
Gluconacetobacter tumulicola sp. nov. and Gluconacetobacter asukensis sp. nov., isolated from the stone chamber interior of the Kitora Tumulus
}

Correspondence

Junta Sugiyama

jsugiyam@tecsrg.co.jp

\author{
Nozomi Tazato, ${ }^{1}$ Miyuki Nishijima, ${ }^{1}$ Yutaka Handa, ${ }^{1}$ Rika Kigawa, ${ }^{2}$ \\ Chie Sano ${ }^{2}$ and Junta Sugiyama ${ }^{3}$ \\ ${ }^{1}$ NCIMB Group, TechnoSuruga Laboratory Co. Ltd, 330 Nagasaki, Shimizu-ku, Shizuoka-shi, \\ Shizuoka 424-0065, Japan \\ ${ }^{2}$ Independent Administrative Institution, National Research Institute for Cultural Properties, \\ 13-43 Ueno-Koen, Taito-ku, Tokyo 110-8713, Japan \\ ${ }^{3}$ TechnoSuruga Laboratory Co. Ltd, Chiba Branch Office \& Lab No. 4 Sanko Bldg, Room 201, \\ 3-1532-13 Hasama-cho, Funabashi-shi, Chiba 274-0822, Japan
}

The Kitora Tumulus, which is located in Asuka-mura (Asuka village), Nara Prefecture, Japan, was built between the late 7 th and early 8 th centuries. It is well known to the people of Japan as a Special Historic Site with polychrome mural paintings. It was discovered in November 1983 and excavated in January/February 2004. At the time of its discovery, the wall paintings were beautiful and vivid. However, cracks on the plaster were obvious and some paintings were loosely held to the rock. The Agency for Cultural Affairs, Japan, decided to relocate the paintings in September 2004; all the paintings on the sidewalls and the star charts on the ceiling were relocated to a controlled environment by the end of 2008. During the relocation, the growth of micro-organisms on the surface of the wall paintings became obvious (Kigawa et al., 2005). In early 2004, white moulds occurred on the surface of the murals. In early 2005, small colonies of viscous gel appeared on

The GenBank/EMBL/DDBJ accession numbers for the 16S rRNA gene sequences of strains K5929-2-1 $b^{\top}$ and $K 8617-1-1 b^{\top}$ are AB627116 and $A B 627120$, respectively.

One supplementary figure and two supplementary tables are available with the online version of this paper. some parts of the inside walls. The formation of biofilms was subsequently confirmed on the surface of the plaster walls of the mural paintings. After the summer of 2005, micro-organism contamination of the stone chamber increased, with gelatinous or viscous gel materials partly covering the plaster wall surface. These biofilms were mainly composed of bacteria, moulds and yeasts. In particular, biofilms had impregnated the surface of the plaster around the ceiling. A few small holes on the plaster walls were confirmed in the stone chamber interior in September 2005 (photos 14 and 15 in Kigawa et al., 2006). These small holes were filled with black gel or viscous materials and increased in size with time (Kigawa et al., 2006).

Initially, common, aerobic micro-organisms were the target for isolation. We isolated a range of micro-organisms, which included moulds, yeasts and bacteria, from viscous gel samples and made preliminary identifications (Kigawa et al., 2006, 2009; Sugiyama et al., 2009).

Among the bacterial isolates, we obtained six isolates (K5929-2-1b ${ }^{\mathrm{T}}$, K8617-1-1b ${ }^{\mathrm{T}}$, K5929-1-1b, K8617-3-4b, K8617-7-3b and K5929-3-1b) of acetic acid bacteria that 
were phylogenetically and phenotypically related to known species of the genus Gluconacetobacter. Navarro \& Komagata (1999) and Yamada \& Yukphan (2008) have shown that Gluconacetobacter could be divided into two groups, i.e. the Gluconacetobacter liquefaciens group (Asai, 1935) - including the type species of the genus - and the Gluconacetobacter xylinus group (Brown, 1886; Yamada et al., 1998), on the basis of DNA G + C content, quinone system and 16S rRNA gene sequence divergence.

In this study, we describe six isolates of acetic acid bacteria that can be assigned to two novel lineages in the $G$. liquefaciens group within the genus Gluconacetobacter. Implications for the biodeterioration of mural paintings and plaster by the strains described will be discussed elsewhere by R. Kigawa and others.

The six acetic acid bacterial strains were isolated on nutrient agar (CM3; Oxoid) or on medium for isolation of acetic acid bacteria (Yamada, 1986), which consisted of $10 \mathrm{~g}$ glucose, $5 \mathrm{ml}$ ethanol, $5 \mathrm{~g}$ yeast extract, $3 \mathrm{~g}$ peptone, $5 \mathrm{~g} \mathrm{CaCO}_{3}$ and $15 \mathrm{~g}$ agar in $900 \mathrm{ml}$ distilled water and $10 \%(\mathrm{v} / \mathrm{v})$ potato extract ( $\mathrm{pH}$ unadjusted). After incubation for 3 days or more at $30{ }^{\circ} \mathrm{C}$, acetic acid bacteria were selected from the plates, where they dissolved the calcium carbonate $\left(\mathrm{CaCO}_{3}\right)$, resulting in clear zones around the colonies. These isolates were subsequently maintained on GYC agar plates (De Ley et al., 1984) comprising (per litre distilled water): $5 \mathrm{~g}$ glucose, $1 \mathrm{~g}$ yeast extract, $3 \mathrm{~g} \mathrm{CaCO}_{3}$ and $2.5 \mathrm{~g}$ agar ( $\mathrm{pH}$ unadjusted). G. liquefaciens NBRC $12388^{\mathrm{T}}$, Gluconacetobacter diazotrophicus DSM $5601^{\mathrm{T}}$, Gluconacetobacter sacchari DSM $12717^{\mathrm{T}}$, Gluconacetobacter johannae DSM $13595^{\mathrm{T}}$ and Gluconacetobacter azotocaptans DSM $13594^{\mathrm{T}}$ were used as reference strains. Details of all strains used in this study are given in Table S1, available in IJSEM Online. The reference strains were cultured according to the recommendations of the respective suppliers.

Genomic DNA was extracted by using the InstaGene Matrix kit (Bio-Rad) according to the manufacturer's instructions. PCR was achieved with PrimeSTAR HS DNA Polymerase (TakaraBio). Thermal cycling was performed by using a GeneAmp PCR System 9600 (Applied Biosystems). Sequencing reactions were performed with a BigDye Terminator v 3.1 Cycle Sequencing kit (Applied Biosystems). Primers used included 9F, 339F, 785F, 1099F, 536R, 802R, 1242R and 1510R (Nakagawa et al., 2002; Uchino et al., 1997). Sequences were determined by using an ABI 3100 DNA sequencer (Applied Biosystems). The respective 16S rRNA gene sequences determined were compared with those retrieved from GenBank/EMBL/ DDBJ by BLAST searches (Altschul et al., 1997). The sequences of the isolated strains were aligned with those of closely related species from these databases by using CLUSTAL W (Thompson et al., 1994) and were edited by eye with the BioEdit program (Hall, 1999) to exclude ambiguous positions and alignment gaps from the analysis. Levels of sequence similarity were calculated and a neighbour-joining evolutionary distance tree (Saitou \& Nei, 1987) was reconstructed by using MEGA ver3.1 (Kumar et al., 2004).

The 16S rRNA gene sequences of strains K5929-2-1b ${ }^{\mathrm{T}}$ and K8617-1-1b ${ }^{\mathrm{T}}$ determined (1453 bp) were compared with those retrieved from public databases. The sequences of strains K5929-2-1b ${ }^{\mathrm{T}}$, K5929-1-1b, K8617-3-4b, K8617-7-3b and K5929-3-1b were related most closely to those of $G$. liquefaciens $\mathrm{NBRC} 12388^{\mathrm{T}}$ (99.0\% similarity), G. sacchari SRI $1794^{\mathrm{T}}(98.4 \%)$ and G. diazotrophicus ATCC $49037^{\mathrm{T}}$ (98.7\%). In contrast, strain K8617-1-1b ${ }^{\mathrm{T}}$ was related most closely to G. liquefaciens NBRC $12388^{\mathrm{T}}(98.8 \%)$, G. sacchari SRI $1794^{\mathrm{T}}(98.8 \%)$ and G. diazotrophicus ATCC $49037^{\mathrm{T}}(98.6 \%)$. The level of $16 \mathrm{~S}$ rRNA gene sequence similarity between strain K5929-2-1b $\mathrm{b}^{\mathrm{T}}$ and strains K59291-1b, K8617-3-4b, K8617-7-3b and K5929-3-1b was $100 \%$, whereas that between strains K8617-1-1b ${ }^{\mathrm{T}}$ and K5929-2$1 \mathrm{~b}^{\mathrm{T}}$ was $99.5 \%$. Levels of $16 \mathrm{~S}$ rRNA gene sequence similarity between the novel isolates and representatives of other genera in the family Acetobacteraceae were lower than $97 \%$. The neighbour-joining phylogenetic trees depicted in Fig. 1 and Fig. S1, and strains K5929-2-1b ${ }^{\mathrm{T}}$ (and K5929-1-1b, K8617-3-4b, K8617-7-3b and K5929-3-1b) and $\mathrm{K} 8617-1-1 \mathrm{~b}^{\mathrm{T}}$ were included in a major cluster containing G. liquefaciens, the type species of the genus, with $92 \%$ bootstrap support (Fig. S1), but formed an independent subgrouping on their own that was tightly clustered away from the type species. The six novel isolates could be divided phylogenetically into two groups, represented by strains $\mathrm{K} 5929-2-1 \mathrm{~b}^{\mathrm{T}}$ and $\mathrm{K} 8617-1-1 \mathrm{~b}^{\mathrm{T}}$, respectively. Recently, the novel genus Ameyamaea (Yukphan et al., 2009) was proposed in the family Acetobacteraceae. According to these authors, this genus is related phylogenetically to the genera Gluconacetobacter and Tanticharoenia (Yukphan et al., 2008). However, the Kitora Tumulus isolates could clearly be differentiated from these two genera based on the results of phylogenetic analysis and levels of 16S rRNA gene sequence similarity.

Cell shape was observed after growth on mannitol agar medium, containing $(\mathrm{w} / \mathrm{v}): 2.5 \%$ mannitol, $0.5 \%$ yeast extract, $0.3 \%$ peptone and $2.0 \%$ agar, adjusted to $\mathrm{pH} 6.0$ (Asai et al., 1964), at $30{ }^{\circ} \mathrm{C}$ for $24 \mathrm{~h}$. Gram staining was carried out by using a Favour G Gram-stain kit (Nissui) according to the manufacturer's instructions. Motility and flagellation were observed with cells cultured on agar slants for $18-24 \mathrm{~h}$ at $20^{\circ} \mathrm{C}$. The arrangement of flagella was observed with a JEM-2000EX transmission electron microscope (JEOL) and flagella were negatively stained with uranyl acetate at $100 \mathrm{kV}$. Physiological and biochemical characterization was performed according to the methods described by Asai et al. (1964), Yamada et al. (1976) and Swings et al. (1992).

Cells of strains K5929-2-1b ${ }^{\mathrm{T}}$ and K8617-1-1b ${ }^{\mathrm{T}}$ were Gramnegative, rod-shaped, aerobic, asporogenous, and motile by means of peritrichous flagella (Fig. 2). They were catalasepositive and oxidase-negative. Strain $\mathrm{K} 5959-2-1 \mathrm{~b}^{\mathrm{T}}$ produced a water-soluble brown pigment on GYC agar, 


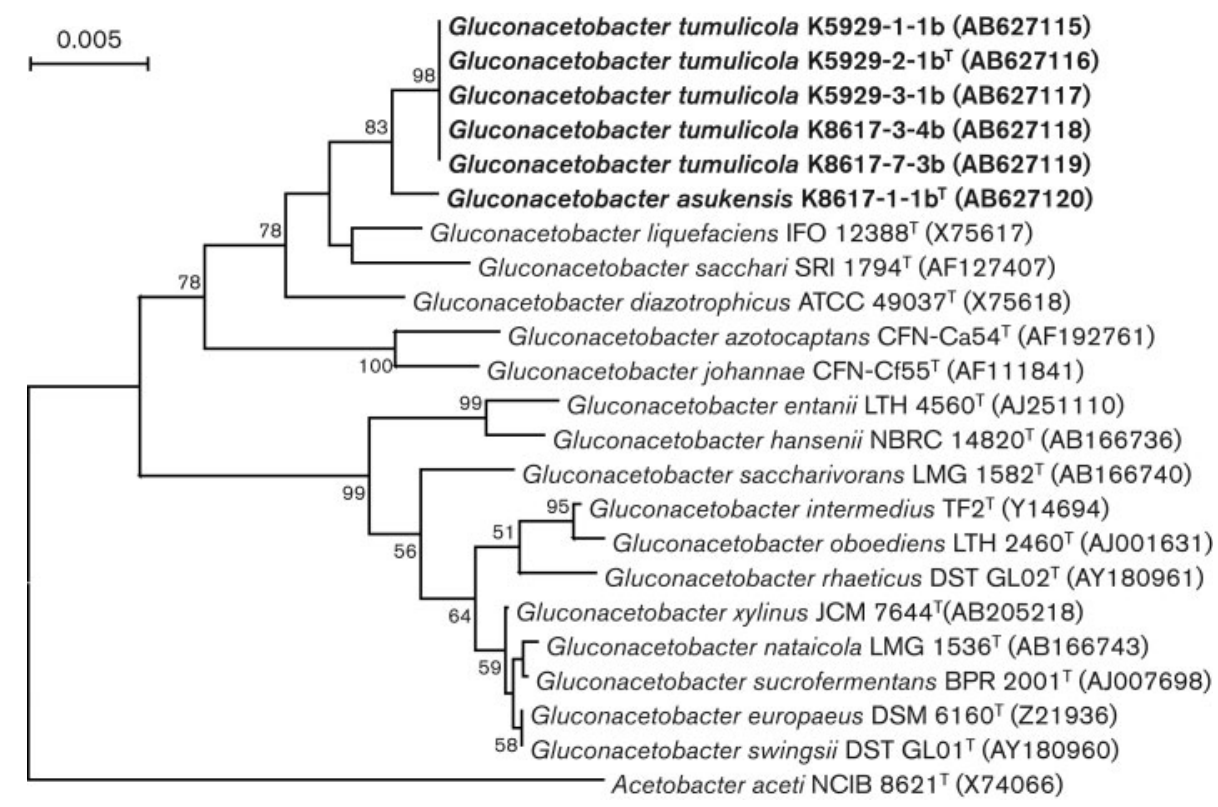

Fig. 1. Neighbour-joining phylogenetic tree based on the nearly complete $16 \mathrm{~S}$ rRNA gene sequences of the six novel isolates and the type strains of recognized species of the genus Gluconacetobacter. Bootstrap values (percentages of 1000 replications) of $>50 \%$ are shown at the respective branch points. Acetobacter aceti NCIB $8621^{\top}$ was used as an outgroup. Bar, 5 changes per 1000 nt positions. An expanded version of this tree is shown in Fig. S1.
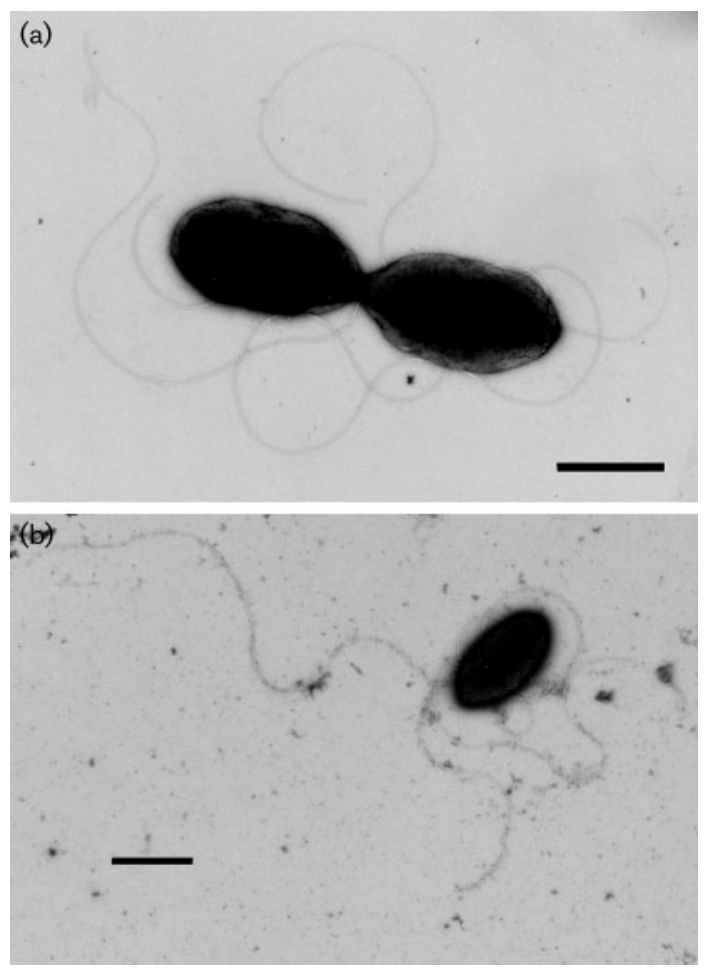

Fig. 2. Transmission electron micrographs of cells of strains K5929-2-1 $\mathrm{b}^{\top}$ (a) and $\mathrm{K} 8617-1-1 \mathrm{~b}^{\top}$ (b), both revealing peritrichous flagella. The two isolates were cultivated on mannitol agar at $20{ }^{\circ} \mathrm{C}$ for $18 \mathrm{~h}$. Bars, $1.0 \mu \mathrm{m}$. whereas strain K8617-1-1b ${ }^{\mathrm{T}}$ did not. Growth occurred at 15-30 ${ }^{\circ} \mathrm{C}$ but not at $37{ }^{\circ} \mathrm{C}$ (optimum $20-30{ }^{\circ} \mathrm{C}$ ). The $\mathrm{pH}$ range for growth was 3.5-6.8. The isolates were capable of acid formation from both glucose and ethanol. Both sodium acetate and sodium lactate were oxidized. Growth was observed on glutamate agar and mannitol agar, but not in $10 \%$ ethanol. Strains K5929-2-1b ${ }^{\mathrm{T}}$ and K8617-1-1b grew on LGI medium (Dutta \& Gachhui, 2007) at $30{ }^{\circ} \mathrm{C}$, which contained no combined nitrogen.

Characteristics that differentiate the two proposed novel species from each other and from their closest phylogenetic neighbours are detailed in Table 1 . Strain K5929-2-1b ${ }^{T}$ could be distinguished from strain K8617-1-1b ${ }^{\mathrm{T}}$ by the production of a water-soluble brown pigment on GYC agar, the ability to grow on $0.1 \%$ sorbitol and myo-inositol as sole carbon sources, ketogenesis from glycerol and the ability to produce 2,5-diketogluconic acid from D-glucose. Strain K5929-2-1 $\mathrm{b}^{\mathrm{T}}$ could be distinguished from G. liquefaciens based on the ability to produce 5-ketogluconic acid from D-glucose. Strain K8617-1-1b ${ }^{\mathrm{T}}$ could be distinguished from $G$. liquefaciens by the ability to produce a watersoluble brown pigment on GYC agar, and the ability to produce 5-ketogluconic acid and 2,5-diketogluconic acid from D-glucose (Table 1).

Fatty acid profiles were determined from cells of the six novel isolates and five reference strains grown for $48 \mathrm{~h}$ at $30{ }^{\circ} \mathrm{C}$ under aerobic conditions on DSM medium 105, Gluconobacter oxydans medium (per litre: $100 \mathrm{~g}$ glucose, $10 \mathrm{~g}$ yeast extract, $20 \mathrm{~g} \mathrm{CaCO}_{3}$ and $15 \mathrm{~g}$ agar; adjusted to 
Table 1. Differential characteristics of strains $K 5929-2-1 b^{\top}$ and $K 8617-1-1 b^{\top}$ and their phylogenetically nearest relatives in the genus Gluconacetobacter

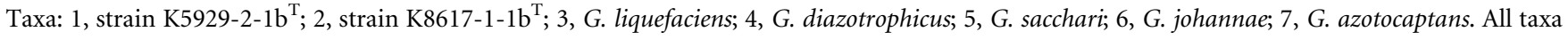
shown were: motile with peritrichous flagella (only data for the novel isolates are from the present study); negative for growth on $10 \%$ ethanol; catalase-positive and oxidase-negative; oxidized acetate and lactate to $\mathrm{CO}_{2}$ and water; positive for acid production from glucose and ethanol; negative for acid production from D-mannitol and sorbitol; positive for growth on glutamate agar and mannitol agar; positive for growth on ethanol as sole carbon source; negative for growth on methanol as sole carbon source; and negative for formation of $\mathrm{H}_{2} \mathrm{~S}$. The major fatty acid and ubiquinone in all taxa were $\mathrm{C}_{18: 1} \omega 7 c$ and Q-10, respectively. Data for all strains were obtained in this study under the same conditions except where indicated. ND, No data.

\begin{tabular}{|c|c|c|c|c|c|c|c|}
\hline Characteristic & 1 & 2 & 3 & 4 & 5 & 6 & 7 \\
\hline \multicolumn{8}{|l|}{ Production of: } \\
\hline Water-soluble brown pigment on GYC plates & + & - & $+^{*}$ & $+\dagger$ & $+\ddagger$ & $+\S$ & $+\S$ \\
\hline Ketogenesis from glycerol & + & - & + & - & - & - & - \\
\hline 5-Ketogluconic acid from D-glucose & - & - & + & - & + & - & - \\
\hline 2-Ketogluconic acid from D-glucose & + & + & + & + & + & - & - \\
\hline Growth on N-free media & + & + & - & + & $\mathrm{ND}$ & + & + \\
\hline Acid production from 1-propanol & + & + & + & + & + & - & - \\
\hline \multicolumn{8}{|l|}{ Growth on sole carbon sources } \\
\hline Sodium acetate & + & + & - & + & + & + & - \\
\hline D-Sorbitol & + & - & - & + & - & + & + \\
\hline myo-Inositol & + & - & - & - & - & - & - \\
\hline
\end{tabular}

${ }^{*}$ Data from Yamada et al. (1997).

$\dagger$ Data from Gillis et al. (1989).

$\$$ Data from Franke et al. (1999).

\$Data from Fuentes-Ramírez et al. (2001).

pH 6.8, see http://www.dsmz.de/microorganisms/medium/ pdf/DSMZ_Medium105.pdf). Cellular fatty acid methyl esters were prepared and analysed by GC (HP6890 series GC system; Hewlett Packard) according to the instructions given for the MIDI Microbial Identification system version 4.5 , and profiles were compared with the database in the Sherlock System 4.5 (Microbial ID; MIDI).

For analyses of respiratory quinones, cells were grown in medium containing (w/v): $2.5 \%$ mannitol, $0.5 \%$ yeast extract and $0.3 \%$ peptone. Cultures were shaken for $72 \mathrm{~h}$ at $28{ }^{\circ} \mathrm{C}$. Quinone extraction and analysis were carried out as described previously (Nishijima et al., 1997).

Cellular fatty acid analysis of strains K5929-2-1b ${ }^{\mathrm{T}}$ and K8617-1-1b $\mathrm{b}^{\mathrm{T}}$ showed that $\mathrm{C}_{18: 1} \omega 7 \mathrm{c}$ was the most abundant component (58.7-63.1\% of the total) (Table 2). Analysis of the respiratory quinones revealed that both strains K5929$2-1 b^{\mathrm{T}}$ and K8617-1-1 $\mathrm{b}^{\mathrm{T}}$ contained ubiquinones, with Q-10 as the major quinone (accounting for $>90 \%$ ) and Q-9 as a minor component $(<10 \%)$. These are common characteristics of strains belonging to the genus Gluconacetobacter (Yamada et al., 1969; Yamada \& Yukphan, 2008). The reference type strains of Gluconacetobacter species used in this study had $\mathrm{C}_{18: 1} \omega 7 c$ and Q-10 as major components.
For determination of the $\mathrm{G}+\mathrm{C}$ content of the genomic DNA and for DNA-DNA hybridization experiments, the genomic DNA of the six novel isolates and of the type strains of the three most closely related species, i.e. $G$. liquefaciens NBRC $12388^{\mathrm{T}}$, G. diazotrophicus DSM $5601^{\mathrm{T}}$ and G. sacchari DSM $12717^{\mathrm{T}}$, was extracted and purified according to the combined methods of Marmur (1961) and Saito \& Miura (1963). The genomic DNA was digested to nucleotides by nuclease P1, by using a DNA-GC kit (Seikagaku Kogyo) according to the procedures described by Katayama-Fujimura et al. (1984). The G+C content of the DNA was determined by HPLC (LC-10; Shimadzu) with an RP Aqueous column $(4.6 \times 250 \mathrm{~mm}$; Nomura Chemical) and a UV-VIS spectrophotometric detector (SPD-10AV; Shimadzu) at $270 \mathrm{~nm}$. Levels of DNA-DNA relatedness were determined by the fluorometric hybridization method on a microdilution plate (Ezaki et al., 1989) at $52{ }^{\circ} \mathrm{C}$ in the presence of $50 \%$ formamide.

The results of the DNA $\mathrm{G}+\mathrm{C}$ content determination and DNA-DNA hybridization experiments are shown in Table S2. The DNA G $+\mathrm{C}$ contents of the six novel isolates were in the range $64.7-65.4 \mathrm{~mol} \%$. These values are consistent with the $\mathrm{G}+\mathrm{C}$ contents of the type strains of $\mathrm{G}$. liquefaciens, G. diazotrophicus and G. sacchari determined herein 
Table 2. Cellular fatty acid compositions of the novel strains and the type strains of closely related Gluconacetobacter species

Strains: 1, K5929-2-1b ${ }^{\mathrm{T}}$; 2, K5929-1-1b; 3, K5929-3-1b; 4, K8617-34b; 5, K8617-7-3b; 6, K8617-1-1b ${ }^{\mathrm{T}}$; 7, G. liquefaciens NBRC $12388^{\mathrm{T}} ; 8$, G. diazotrophicus DSM 5601 ${ }^{\mathrm{T}}$; 9, G. sacchari DSM $12717^{\mathrm{T}} ; 10, \mathrm{G}$. azotocaptans DSM $13594^{\mathrm{T}}$; 11, G. johannae DSM $13595^{\mathrm{T}}$. The content of each fatty acid is expressed as a percentage of the total. Fatty acids present at lower than $0.5 \%$ in all strains are not shown; -, not detected. Data were obtained in this study by using the same cultivation conditions (DSM medium 105 containing $10 \%$ glucose at $30{ }^{\circ} \mathrm{C}$ for 2 days) and the same analytical method (MIDI system).

\begin{tabular}{|c|c|c|c|c|c|c|c|c|c|c|c|}
\hline Fatty acid & 1 & 2 & 3 & 4 & 5 & 6 & 7 & 8 & 9 & 10 & 11 \\
\hline \multicolumn{12}{|l|}{ Saturated } \\
\hline $\mathrm{C}_{12: 0}$ & - & - & - & - & - & 0.6 & 2.1 & 1.2 & 1.1 & 1.3 & 0.9 \\
\hline $\mathrm{C}_{14: 0}$ & 3.0 & 4.9 & 3.7 & 2.9 & 2.6 & 4.1 & 4.1 & 4.5 & 2.2 & 3.1 & 3.3 \\
\hline $\mathrm{C}_{16: 0}$ & 11.2 & 15.8 & 11.2 & 11.5 & 9.8 & 9.3 & 8.4 & 7.4 & 9.2 & 14.0 & 10.5 \\
\hline $\mathrm{C}_{17: 0}$ & - & - & 0.5 & - & - & 0.6 & - & - & - & - & 0.3 \\
\hline $\mathrm{C}_{18: 0}$ & 3.4 & 0.8 & 3.2 & 3.7 & 5.2 & 3.4 & 2.3 & 1.4 & 1.4 & 1.2 & 1.4 \\
\hline \multicolumn{12}{|l|}{ Unsaturated } \\
\hline $\mathrm{C}_{18: 1} \omega 7 c$ & 62.8 & 58.7 & 61.3 & 62.4 & 62.0 & 63.1 & 62.6 & 64.3 & 63.8 & 60.7 & 63.7 \\
\hline \multicolumn{12}{|l|}{ Hydroxylated } \\
\hline $\mathrm{C}_{14: 0} 2-\mathrm{OH}$ & 5.5 & 6.8 & 5.3 & 5.2 & 4.8 & 4.5 & 4.3 & 5.5 & 5.8 & 5.9 & 6.3 \\
\hline $\mathrm{C}_{16: 0} 2-\mathrm{OH}$ & 7.1 & 4.7 & 7.7 & 7.0 & 7.2 & 6.3 & 7.7 & 8.4 & 8.1 & 5.3 & 5.5 \\
\hline $\mathrm{C}_{18: 1} 2-\mathrm{OH}$ & 0.9 & - & 1.2 & 0.7 & - & 2.2 & - & 0.9 & 1.8 & - & 0.8 \\
\hline $\mathrm{C}_{16: 0} 3-\mathrm{OH}$ & 2.8 & 2.9 & 3.1 & 2.9 & 3.0 & 2.7 & 3.3 & 3.0 & 3.4 & 3.4 & 3.4 \\
\hline $\mathrm{C}_{18: 0} 3-\mathrm{OH}$ & 0.9 & 0.6 & 1.0 & 1.1 & 1.3 & 0.9 & 1.3 & 0.9 & 1.1 & 1.2 & 1.2 \\
\hline $\mathrm{C}_{19: 0} \omega 8 c$ cyclo & 1.4 & 1.9 & 0.8 & 1.5 & 2.9 & 0.6 & 2.1 & 1.4 & 0.9 & 2.2 & 1.1 \\
\hline \multicolumn{12}{|l|}{ Summed features ${ }^{*}$} \\
\hline 2 & 1.0 & 1.2 & 1.1 & 1.1 & 1.2 & 1.2 & 1.8 & 1.1 & 1.3 & 1.1 & 1.4 \\
\hline 3 & - & 1.9 & - & - & - & - & - & - & - & 0.8 & 0.4 \\
\hline
\end{tabular}

*Summed features represent two or more components that cannot be separated by GLC with the MIDI system. Summed feature 2 comprises iso- $\mathrm{C}_{16: 1}$ I and/or $\mathrm{C}_{14: 0} 3-\mathrm{OH}$; summed feature 3 comprises iso- $\mathrm{C}_{15: 0} 2-\mathrm{OH}$ and/or $\mathrm{C}_{16: 1} \omega 7 c$.

and with published data (Yamada et al., 1997; Gillis et al., 1989; Franke et al., 1999). Reciprocal hybridization experiments were performed with the six novel isolates and the type strains of G. liquefaciens, G. diazotrophicus and G. sacchari. In each assay, each combination was tested three times and mean percentages are indicated in Table S2. Levels of DNA-DNA relatedness obtained were greater than $80 \%$ between each combination of the novel isolates except strain K8617-1-1 $\mathrm{b}^{\mathrm{T}}$. The level of DNA-DNA relatedness between strains K5929-2-1 $\mathrm{b}^{\mathrm{T}}$ and $\mathrm{K} 8617-1-1 \mathrm{~b}^{\mathrm{T}}$ was below $51 \%$. Levels of DNA-DNA relatedness of $\leqslant 28 \%$ were found between strain K5929-2-1b ${ }^{\mathrm{T}}$ and each of the type strains of G. liquefaciens, G. diazotrophicus and G. sacchari, and also below $21 \%$ between strain K8617-1$1 \mathrm{~b}^{\mathrm{T}}$ and each of the type strains of G. liquefaciens, G. diazotrophicus and G. sacchari. These values clearly indicated that strains $\mathrm{K} 5929-2-1 \mathrm{~b}^{\mathrm{T}}$ and $\mathrm{K} 8617-1-1 \mathrm{~b}^{\mathrm{T}}$ represented two novel genospecies assignable to the genus Gluconacetobacter based on the $70 \%$ recommended guideline for species delineation (Wayne et al., 1987).
Polychrome mural paintings of both Takamatsuzuka and Kitora Tumuli were drawn directly onto thin calcium carbonate plaster in the stone chambers (e.g. Kigawa et al., 2009). Many members of the G. liquefaciens group have been isolated from plant material such as fruits, flowers, sugar cane and coffee plants, whereas strains of the $G$. xylinus group have largely been isolated from fermented foods such as vinegar, nata de coco (fermented coconut water) and fermented teas (Yamada \& Yukphan, 2008). There is no record of isolation of acetic acid bacteria from ancient buildings, particularly mural paintings or plaster walls. The isolation of Gluconacetobacter bacteria in this study is thus of note. In addition, our previous experiments (Kigawa et al., 2009) revealed that strain K5929-2-1b ${ }^{\mathrm{T}}$ dissolved calcium carbonate and produced a water-soluble brownish pigment in GYC medium. Other experiments (Sano et al., 2010) have also shown that production of acetic acid by these six Gluconacetobacter isolates (170$2200 \mathrm{mg} \mathrm{l}^{-1}$ ) was higher than that exhibited by $G$. diazotrophicus DSM $5601^{\mathrm{T}}\left(90 \mathrm{mg} \mathrm{l}^{-1}\right)$. As a result, these isolates caused a large decrease in $\mathrm{pH}$ (i.e. by up to $3.85 \mathrm{pH}$ units). These data suggest that Gluconacetobacter species are involved in the biodeterioration of mural paintings and plaster. Further discussions will be made elsewhere by R. Kigawa and others.

In conclusion, the results of our polyphasic systematic approach support the recognition of two novel species of the genus Gluconacetobacter (Acetobacteraceae, Rhodospirillales, Alphaproteobacteria), for which we propose the names Gluconacetobacter tumulicola sp. nov. and Gluconacetobacter asukensis sp. nov.

\section{Description of Gluconacetobacter tumulicola sp. nov.}

Gluconacetobacter tumulicola [tu.mu.li'co.la. L. n. tumulus tumulus or tomb; L. suff. -cola (from L. n. incola) dweller; N.L. n. tumulicola tumulus dweller].

Cells are Gram-negative rods measuring 0.7-0.8 $\times 1.2$ $2.0 \mu \mathrm{m}$ and are motile by peritrichous flagella. Strictly aerobic, catalase-positive and oxidase-negative. A watersoluble brown pigment is produced on GYC agar. Lactate and acetate are oxidized to $\mathrm{CO}_{2}$ and $\mathrm{H}_{2} \mathrm{O}$. Acetic acid is not required for growth. Grows at $\mathrm{pH} 3.0-6.8$ and at $15-30{ }^{\circ} \mathrm{C}$ (optimum $20-30{ }^{\circ} \mathrm{C}$ ). Acid is produced from glucose, 1propanol and ethanol, but not from D-mannitol or sorbitol. Ketogenesis occurs in the presence of glycerol. 2-Ketogluconic acid and 2,5-diketogluconic acid are produced from D-glucose, but 5-ketogluconic acid is not. $\gamma$ Pyrone is produced from D-fructose. Grows on glutamate agar and mannitol agar, but not on $10 \%$ ethanol. Growth occurs on $0.1 \%$ ethanol, sodium acetate, 1-propanol, mesoribitol, D-mannitol, sorbitol, myo-inositol, D-ribose, D-fructose, D-glucose, calcium DL-gluconate, sucrose and sodium DLlactate as sole carbon sources, but not on methanol, L-arabitol, meso-xylitol, dulcitol, D-xylose, D-lyxose, D-fucose, L-arabinose, D-galactose, D-mannose, L-sorbose, cellobiose, maltose, 
raffinose, dextrin, sodium malonate, sodium L-malate or sodium citrate. Growth occurs on nitrogen-free LGI medium at $30{ }^{\circ} \mathrm{C}$. The ubiquinone system consists of Q-10 as the major component and Q-9 as a minor component. $\mathrm{C}_{18: 1} \omega 7 c$ is the major fatty acid.

The type strain, K5929-2-1b ${ }^{\mathrm{T}}\left(=\mathrm{JCM} 17774^{\mathrm{T}}=\mathrm{NCIMB}\right.$ $14760^{\mathrm{T}}$ ), was isolated from a black viscous substance in a plaster hole at the centre of the ceiling in the stone chamber of the Kitora Tumulus in Asuka village, Nara Prefecture, Japan. The DNA $\mathrm{G}+\mathrm{C}$ content of the type strain is $64.7 \mathrm{~mol} \%$. K5929-1-1b (=JCM 17773), K8617-3-4b (=JCM 17776), K8617-7-3b (=JCM 17777) and K59293-1b (=JCM 17775) are additional strains of the species.

\section{Description of Gluconacetobacter asukensis sp. nov.}

Gluconacetobacter asukensis (a.suk.en'sis. N.L. masc. adj. asukensis of or belonging to Asuka village, referring to the isolation of the type strain from Asuka village).

Cells are Gram-negative rods measuring 0.8-0.9 $\times 1.2$ $2.0 \mu \mathrm{m}$ and are motile by peritrichous flagella. Strictly aerobic, catalase-positive and oxidase-negative. A watersoluble brown pigment is not produced on GYC agar. Lactate and acetate are oxidized to $\mathrm{CO}_{2}$ and $\mathrm{H}_{2} \mathrm{O}$. Acetic acid is not required for growth. Grows at $\mathrm{pH} 3.0-6.8$ and at $15-30{ }^{\circ} \mathrm{C}$ (optimum $20-30{ }^{\circ} \mathrm{C}$ ). Acid is produced from glucose, 1-propanol and ethanol, but not from D-mannitol or sorbitol. Ketogenesis occurs in the presence of glycerol. 2-Ketogluconic acid is produced from D-glucose, but 5ketogluconic acid and 2,5-diketogluconic are not. $\gamma$-Pyrone is produced from D-fructose. Grows on glutamate agar and mannitol agar, but not on $10 \%$ ethanol. Growth occurs on $0.1 \%$ ethanol, sodium acetate, 1-propanol, meso-ribitol, Dmannitol, D-ribose, D-fructose, D-glucose, calcium DLgluconate, sucrose and sodium DL-lactate as sole carbon sources, but not on methanol, L-arabitol, meso-xylitol, sorbitol, myo-inositol, dulcitol, D-xylose, D-lyxose, Dfucose, L-arabinose, D-galactose, D-mannose, L-sorbose, cellobiose, maltose, raffinose, dextrin, sodium malonate, sodium L-malate or sodium citrate. Growth occurs on nitrogen-free LGI medium at $30{ }^{\circ} \mathrm{C}$. The ubiquinone system consists of Q-10 as the major component and Q9 as a minor component. $\mathrm{C}_{18: 1} \omega 7 c$ is the major fatty acid.

The type strain, K8617-1-1b $\mathrm{b}^{\mathrm{T}}\left(=\mathrm{JCM} 17772^{\mathrm{T}}=\mathrm{NCIMB}\right.$ $\left.14759^{\mathrm{T}}\right)$, was isolated from a brown viscous gel on the north-east area of the ceiling in the stone chamber of the Kitora Tumulus in Asuka village, Nara Prefecture, Japan. The DNA G + C content of the type strain is $65.4 \mathrm{~mol} \%$.

\section{Acknowledgements}

Permission for this study was granted by the Agency for Cultural Affairs, Japan. We thank the curators of NITE-Biological Resource Center (NBRC) in Kazusa and Deutsche Sammlung von Mikroorganismen und Zellkulturen GmbH (DSMZ) in Braunschweig for providing the type strains of Gluconacetobacter species. We thank Dr
Peter Green of NCIMB Ltd in Aberdeen for suggested improvements to the English text. We also thank the editor and anonymous reviewers for their helpful comments and suggestions. Part of this study was financially supported by Grants-in-Aid for Scientific Research (A) from the Japan Society for the Promotion of Science (JSPS) (no. 19200057 to C. S., 2007-2011).

\section{References}

Altschul, S. F., Madden, T. L., Schäffer, A. A., Zhang, J., Zhang, Z., Miller, W. \& Lipman, D. J. (1997). Gapped BLAST and PSI-BLAST: a new generation of protein database search programs. Nucleic Acids Res 25, 3389-3402.

Asai, T. (1935). [Taxonomic studies on acetic acid bacteria and allied oxidative bacteria isolated from fruits: a new classification of the oxidative bacteria]. J Agric Chem Soc Japan 11, 674-708 (in Japanese).

Asai, T., Lizuka, H. \& Komagata, K. (1964). The flagellation and taxonomy of genera Gluconobacter and Acetobacter with reference to the existence of intermediate strains. J Gen Appl Microbiol 10, 95-126.

Brown, A. J. (1886). On an acetic ferment which forms cellulose. J Chem Soc Trans 49, 432-439.

De Ley, J., Swings, J. \& Gosselé, F. (1984). Genus I. Acetobacter Beijerinck 1898, 215 ${ }^{\mathrm{AL}}$. In Bergey's Manual of Systematic Bacteriology, vol. 1, pp. 268-274. Edited by N. R. Krieg \& J. G. Holt. Baltimore: Williams \& Wilkins.

Dutta, D. \& Gachhui, R. (2007). Nitrogen-fixing and cellulose-producing Gluconacetobacter kombuchae sp. nov., isolated from Kombucha tea. Int J Syst Evol Microbiol 57, 353-357.

Ezaki, T., Hashimoto, Y. \& Yabuuchi, E. (1989). Fluorometric deoxyribonucleic acid-deoxyribonucleic acid hybridization in microdilution wells as an alternative to membrane filter hybridization in which radioisotopes are used to determine genetic relatedness among bacterial strains. Int J Syst Bacteriol 39, 224-229.

Franke, I. H., Fegan, M., Hayward, C., Leonard, G., Stackebrandt, E. \& Sly, L. I. (1999). Description of Gluconacetobacter sacchari sp. nov., a new species of acetic acid bacterium isolated from the leaf sheath of sugar cane and from the pink sugar-cane mealy bug. Int $J$ Syst Bacteriol 49, 1681-1693.

Fuentes-Ramírez, L. E., Bustillos-Cristales, R., Tapia-Hernández, A., Jiménez-Salgado, T., Wang, E. T., Martínez-Romero, E. \& CaballeroMellado, J. (2001). Novel nitrogen-fixing acetic acid bacteria, Gluconacetobacter johannae sp. nov. and Gluconacetobacter azotocaptans sp. nov., associated with coffee plants. Int J Syst Evol Microbiol 51, 1305-1314.

Gillis, M., Kersters, K., Hoste, B., Janssens, D., Kroppenstedt, R. M., Stephan, M. P., Teixeira, K. R. S., Döbereiner, J. \& Deley, J. (1989). Acetobacter diazotrophicus sp. nov., a nitrogen-fixing acetic acid bacterium associated with sugarcane. Int J Syst Bacteriol 39, 361-364.

Hall, T. A. (1999). BioEdit: a user-friendly biological sequence alignment editor and analysis program for Windows 95/98/NT. Nucleic Acids Symp Ser 41, 95-98.

Katayama-Fujimura, Y., Komatsu, Y., Kuraishi, H. \& Kaneko, T. (1984). Estimation of DNA base composition by high performance liquid chromatography of its nuclease P1 hydrolysate. Agric Biol Chem 48, 3169-3172.

Kigawa, R., Sano, C., Mabuchi, H. \& Miura, S. (2005). [Investigation of biological issues in the Kitora Tumulus during its restoration work]. Sci Conserv 44, 165-171 (in Japanese).

Kigawa, R., Mabuchi, H., Sano, C. \& Miura, S. (2006). [Investigation of biological issues in the Kitora Tumulus during its restoration work (2)]. Sci Conserv 45, 93-105 (in Japanese). 
Kigawa, R., Sano, C., Mabuchi, H., Kiyuna, T., Tazato, N., Nishijima, M. \& Sugiyama, J. (2009). [Biological issues in Kitora Tumulus during relocation works of the mural paintings]. Sci Conserv 48, 167-174 (in Japanese).

Kumar, S., Tamura, K. \& Nei, M. (2004). MEGA3: integrated software for molecular evolutionary genetics analysis and sequence alignment. Brief Bioinform 5, 150-163.

Marmur, J. (1961). A procedure for the isolation of deoxyribonucleic acid from micro-organisms. J Mol Biol 3, 208-218.

Nakagawa, Y., Sakane, T., Suzuki, M. \& Hatano, K. (2002). Phylogenetic structure of the genera Flexibacter, Flexithrix, and Microscilla deduced from 16S rRNA sequence analysis. J Gen Appl Microbiol 48, 155-165.

Navarro, R. R. \& Komagata, K. (1999). Differentiation of Gluconacetobacter liquefaciens and Gluconacetobacter xylinus on the basis of DNA base composition, DNA relatedness, and oxidation products from glucose. J Gen Appl Microbiol 45, 7-15.

Nishijima, M., Araki-Sakai, M. \& Sano, H. (1997). Identification of isoprenoid quinones by frit-FAB liquid chromatography-mass spectrometry for the chemotaxonomy of microorganisms. J Microbiol Methods 28, 113-122.

Saito, H. \& Miura, K. I. (1963). Preparation of transforming deoxyribonucleic acid by phenol treatment. Biochim Biophys Acta 72, 619-629.

Saitou, N. \& Nei, M. (1987). The neighbor-joining method: a new method for reconstructing phylogenetic trees. Mol Biol Evol 4, 406425.

Sano, C., Nishijima, M., Kiyuna, T., Kigawa, R. \& Sugiyama, J. (2010). [Carboxylic acids productivity of major microorganisms isolated from the stone chamber interior of Takamatsuzuka Tumulus and Kitora Tumulus, Nara Prefecture, Japan]. Sci Conserv 49, 209-218 (in Japanese).

Sugiyama, J., Kiyuna, T., An, K.-D., Nagatsuka, Y., Handa, Y., Tazato, N., Hata-Tomida, J., Nishijima, M., Koide, T. \& other authors (2009). Microbiological survey of the stone chambers of Takamatsuzuka and Kitora tumuli, Nara Prefecture, Japan: a milestone in elucidating the cause of biodeterioration of mural paintings. In Study of Environmental Conditions Surrounding Cultural Properties and Their Protective Measures, pp. 51-73. Edited by C. Sano. Tokyo: National Research Institute for Cultural Properties, Tokyo.

Swings, J., Gillis, M. \& Kersters, K. (1992). Phenotypic identification of acetic acid bacteria. In Identification Methods in Applied and Environmental Microbiology, pp. 103-110. Edited by R. G. Board, D. Jones \& F. A. Skinner. Oxford: Blackwell Scientific.
Thompson, J. D., Higgins, D. G. \& Gibson, T. J. (1994). CLUSTAL W: improving the sensitivity of progressive multiple sequence alignment through sequence weighting, position-specific gap penalties and weight matrix choice. Nucleic Acids Res 22, 4673-4680.

Uchino, Y., Yokota, A. \& Sugiyama, J. (1997). Phylogenetic position of the marine subdivision of Agrobacterium species based on $16 \mathrm{~S}$ rRNA sequence analysis. J Gen Appl Microbiol 43, 243-247.

Wayne, L. G., Brenner, D. J., Colwell, R. R., Grimont, P. A. D., Kandler, O., Krichevsky, M. I., Moore, L. H., Moore, W. E. C., Murray, R. G. E. \& other authors (1987). International Committee on Systematic Bacteriology. Report of the ad hoc committee on reconciliation of approaches to bacterial systematics. Int J Syst Bacteriol 37, 463-464.

Yamada, Y. (1986). Acetic acid bacteria. In Methods for the Isolation of Microorganisms, pp. 454-457. Edited by K. Yamasato, S. Udagawa, T. Kodama \& T. Morichi. Tokyo: R \& D Planning (in Japanese).

Yamada, Y. \& Yukphan, P. (2008). Genera and species in acetic acid bacteria. Int J Food Microbiol 125, 15-24.

Yamada, Y., Aida, K. \& Uemura, T. (1969). Enzymatic studies on the oxidation of sugar and sugar alcohol. V. Ubiquinone of acetic acid bacteria and its relation to classification of Gluconobacter and Acetobacter, especially of the so-called intermediate strains. J Gen Appl Microbiol 15, 181-196.

Yamada, Y., Okada, Y. \& Kondo, K. (1976). Isolation and characterization of "polarly flagellated intermediate strains" in acetic acid bacteria. J Gen Appl Microbiol 22, 237-245.

Yamada, Y., Hoshino, K. \& Ishikawa, T. (1997). The phylogeny of acetic acid bacteria based on the partial sequences of $16 \mathrm{~S}$ ribosomal RNA: the elevation of the subgenus Gluconoacetobacter to the generic level. Biosci Biotechnol Biochem 61, 1244-1251.

Yamada, Y., Hoshino, K. \& Ishikawa, T. (1998). Gluconacetobacter corrig. (Gluconoacetobacter [sic]). In Validation of Publication of New Names and New Combinations Previously Effectively Published Outside the IJSB, List no. 64. Int J Syst Bacteriol 48, 327-328.

Yukphan, P., Malimas, T., Muramatsu, Y., Takahashi, M., Kaneyasu, M., Tanasupawat, S., Nakagawa, Y., Suzuki, K. I., Potacharoen, W. \& Yamada, Y. (2008). Tanticharoenia sakaeratensis gen. nov., sp. nov., a new osmotolerant acetic acid bacterium in the $\alpha$-Proteobacteria. Biosci Biotechnol Biochem 72, 672-676.

Yukphan, P., Malimas, T., Muramatsu, Y., Takahashi, M., Kaneyasu, M., Potacharoen, W., Tanasupawat, S., Nakagawa, Y., Hamana, K. \& other authors (2009). Ameyamaea chiangmaiensis gen. nov., sp. nov., an acetic acid bacterium in the $\alpha$-Proteobacteria. Biosci Biotechnol Biochem 73, 2156-2162. 